\title{
Academic Status at Minnesota
}

\author{
BY EDWARD B. STANFORD
}

PRIOR to the middle 1950 s, only the university librarian and the assistant university librarian held academic appointments in the University of Minnesota. One effort had been made, at an earlier date, to change the professional staff to faculty status, but this was unsuccessful. In 1955 it became possible to obtain full faculty rank for the heads of the major departments in the library system, but it was not until two years ago, in 1962 , that it seemed feasible to make a further attempt to extend this status to other professional positions.

For some time the university library had been experiencing increased difficulty in attracting and retaining well-qualified professional staff members. Rigid salary limitations governed its classified positions under Civil Service. This permitted almost no flexibility in recognizing superior abilities. Salary increases were held to an annual 4 per cent change within a six-step range, beyond which staff members could not advance without a job reclassification or promotion to a different position. Under this system a good many staff members were "frozen" at their civil service maximums, and reward for individual merit was nearly impossible. It was clear that the time had come to reopen the question of academic status for more professional positions.

Drawing upon various statements in the professional literature in support of the proposal, it was decided to request a change for a number of positions with policy responsibilities and those in which specialized professional and educational responsibilities were most nearly comparable to those of the faculty. Accordingly, it was requested that positions in the following three groups be removed from their previous civil service classifications
Mr. Stanford is Director of Libraries at the University of Minnesota.

and transferred to the rank of instructor and librarian in the academic staff.

1. Assistant department heads in major departments in the university library system, such as: assistant head of the reference department, assistant librarian of the bio-medical library, and assistant law librarian.

2. Heads of divisions within the various major departments, such as the serials, gifts, and exchange division in the acquisitions department, the social science division in the catalog department, the interlibrary loan division in the reference department, the periodical room in the circulation department, university archives in the department of special collections, and the reference division in the agriculture library.

3. Librarians in charge of units for which specialized subject or language competence is needed in addition to the basic bachelor and masters degree, such as the education library, the chemistry library, the music library, the map library, the engineering library, and the Ames library of South Asia.

Within these categories some fortythree positions were involved, and it was pointed out that they all carry responsibilities at the policy level or call for specialized subject or language competence well beyond that required for initial professional positions.

In due course, following extended consultations with the vice-president for academic administration, these criteria were approved, and on July 1, 1963, the change was made, bringing the total number of library positions with full academic status and faculty rank to sixty, 
including the various department heads.

There still remain some forty professional positions under civil service at the junior librarian and the librarian levels (the first two professional grades). Since all positions in the two higher professional grades (senior librarian and principal librarian) met the criteria for academic status, these classifications, to all intents and purposes, no longer exist in the personnel structure.

This change has given opportunity for the first time to recognize individual merit in making salary increases and promotions, and it has also removed the almost automatic one-step salary increase, as well as the rigid grade maximums that had prevailed under civil service. It has entitled a large number of the staff to the full faculty insurance and retirement benefits, as well as faculty club privileges and the same voting rights with respect to the University Senate that are granted to all faculty members of equivalent rank.

Now that cognizance can be taken of individual merit in determining salary increases Minnesota has begun to explore the problem of performance evaluation, so that annual recommendations can be documented to assure equity in treatment among the various library departments.

Early in 1964 each department head submitted suggestions of various evaluative criteria that might be appropriate for academic positions in the library. These were discussed at length, and they were then combined into an evaluation or appraisal form, to provide guidelines for department heads in making recommendations for the 1964-65 budget. As soon as the form was adopted, it was distributed to the library staff.

Since department heads do not uniformly know of all of the outside activities or contributions of individual staff members that should be recognized and considered in recommending salary adjustments, each academic staff member is asked, on this form, to list such items as his publications, courses taken, commit- tee work, talks given, and other appropriate activities or special projects he has undertaken during the past year that are relevant to the appraisal of his performance and development.

In the development of this form it was emphasized that while research and publication are important aspects of academic work, professional activities in the selection, acquisition, description, and interpretation of library resources are equally deserving of recognition. Similarly, while leadership and supervisory abilities are essential in some positions, these qualities are not needed in others. Advancement in career opportunities should be determined on the basis of individual excellence wherever it occurs, and not on the accident of the kind of work or departmental location of an individual, or whether his responsibilities are primarily scholarly or administrative in nature.

It was agreed that in the use of this form the department head's over-all evaluation of the individual, rather than any quantitative or graded weighting of various criteria, should be used in determining recommendations for salary increases or possible changes in rank.

No plans exist at present to extend academic status to include all professional librarians, but individual positions may be transferred to this group from time to time, and some new positions will undoubtedly be established within the academic group, as funds for additional staff become available.

Promotions to assistant, associate and full professor are now possible for librarians at the University of Minnesota, as they are able to meet the qualifications expected of other faculty members for such appointments. This is not necessary to achieve permanent status, however, for under an amendment to the university tenure code, all incumbents whose positions were changed to academic status retain tenure, and the library may now recommend indefinite tenure at the instructor level as well as at the various higher ranks. 